\title{
Online traceability for Halal product information: perceptions of Muslim consumers in Indonesia \\ by Djoko Sayogo
}

Submission date: 24-Mar-2019 07:52PM (UTC-0700)

Submission ID: 1099096973

File name: uct_information_perceptions_of_Muslim_consumers_in_Indonesia.pdf (641.26K) Word count: 9932

Character count: 56224 


\title{
Thank you for using the University at Albany's Interlibrary Loan Service
}

\author{
NOTICE WARNING CONCERNING COPYRIGHT RESTRICTIONS
}

The copyright law of the United States (Title 17, United States Code) governs the making of photocopies or other reproductions of copyrighted material. Under certain conditions specified in the law, libraries and archives are authorized to furnish a photocopy or other reproduction. One of these specific conditions is that the photocopy or reproduction is not to be "used for any purpose other than private study, scholarship, or research." If a user makes a request for, or later uses, a photocopy or reproduction for purposes in excess of "fair use," that user may be liable for copyright infringement. This institution reserves the right to refuse a copying order if, in its judgment, fulfillment of the order would involve violation of copyright law.

\section{Questions?}

\section{Call 442-3613 from 10:00 4:30 (weekdays)}

or

Send email to libill@albany.edu 


\section{eemeraldinsight}

\section{Journal of Islamic Marketing}

Online traceability for Halal product information: perceptions of Muslim consumers in Indonesia

Djoko Sigit Sayogo,

\section{Article information:}

To cite this document:

Djoko Sigit Sayogo, "Online tt 1 ceability for Halal product information: perceptions of Muslim consumers in Indonesia", Journal of Islamic Marketing, https://doi.org/10.1108/JIMA-07-2016-0057

Permanent link to this document:

https://doi.org/10.1108/JIMA-07-2016-0057

Downloaded on: 12 January 2018, At: 09:40 (PT)

References: this document contains references to 0 other documents.

To copy this document: permissions@emeraldinsight.com

The fulltext of this document has been downloaded 13 times since $2017^{*}$

\section{Users who downloaded this article also downloaded:}

(2017),"Investigating the consumer behavior for halal endorsed products: Case of an emerging Muslim market", Journal of JIMA-09-2015-0068</a>

"Determinants of halal purchasing intentions: evidences from UK", Journal of Islamic Marketing, Vol. 0 Iss ja pp. 00-00<a href="https://doi. org/10.1108/JIMA-02-2016-0013">https://doi.org/10.1108/JIMA-02-2016-0013</a>

Access to this document was granted through an Emerald subscription provided by emerald-srm:173748 []

\section{For Authors}

If you would like to write for this, or any other Emerald publication, then please use our Emerald for Authors service information about how to choose which publication to write for and submission guidelines are available for all. Please visit www.emeraldinsight.com/authors for more information.

\section{About Emerald www.emeraldinsight.com}

Emerald is a global publisher linking research and practice to the benefit of society. The company manages a portfolio of more than 290 journals and over 2,350 books and book series volumes, as well as providing an extensive range of online products and additional customer resources and services.

Emerald is both COUNTER 4 and TRANSFER compliant. The organization is a partner of the Committee on Publication Ethics (COPE) and also works with Portico and the LOCKSS initiative for digital archive preservation.

*Related content and download information correct at time of download. 
Online traceability for Halal product information: perceptions of Muslim consumers in

\author{
Indonesia
}

\begin{abstract}
Purpose - This article provides a preliminary understanding of factors that contribute to consumer perceptions of value and usefulness regarding online traceability for product compliance to Halal principles.

Design/methodology/approach - In total, 160 usable questionnaire were obtained from a large Muslim University in Indonesia through a survey. The data was tested using Multivariate Regression Analysis

Findings - The current study suggests that Muslim consumers in Indonesia perceive the ability to trace a product's compliance to Halal principles as useful and important. The Muslim consumer's perception of online traceability as useful is influenced by three main factors: the consumer's disposition to trust, a healthy lifestyle, and the reputation of the company as well as the certification bodies.

Social implications - Our findings suggest that ICTs play an instrumental role in facilitating smart food safety policies by fostering positive changes in consumer behavior, specifically in supporting Halal and healthy consumption.

Originality/value - Online traceability for Halal product is a novel issue that is yet to be examined empirically in the context of Indonesia. This research should be of value to those who have an interest in assessing the importance of online traceability to enhance assessment of product information, particularly in developing countries.

Keywords: Halal certification, online traceability, product information, consumer trust
\end{abstract}

\title{
1. Introduction
}

Halal food represents a global evolving market. The combined value of Halal markets worldwide reached US\$1.29 trillion in 2015 , which is close to twice the consumption spending in the United States (US\$ 768 billion) (ITC, 2015; Lever \& Miele, 2012). Unfortunately, trusting the legitimacy of a Halal product to abide by all Halal principles becomes challenging in an everexpanding market due to information asymmetry. The asymmetry of information, an imbalance of information between buyer and seller (Eisenhardt, 1989), for the most part, emerges from the lengthening of the supply chain for Halal products. In the global market, consumers lose the 
ability to discern whether or not products have been processed in adherence to the Islamic Sharia principle (Verbeke et al, 2013). Consumers must change their perception of products claiming Halal. In local markets with short supply chains, consumers rely on personal trust when choosing products in compliance with Halal principles (Campbell et al, 2011). For instance, consumers only buy from local butchers whom they know and trust. In the global market, consumers must shift to institutional trust by relying on limited information provided on the product packaging (Luna-reyes et al, 2014) such as the Halal logo and certification.

Still, a large numbers of Halal certification bodies currently exist. As of 2014, there were more than 400 Halal certification bodies, and each had their own certification processes (Tieman, 2015). These distinct processes make it difficult to trust adherence to Halal principles based on the Halal logo alone: the differing processes propagate misuse of the Halal logo (Hava, 2009; van der Spiegel et al, 2012). Furthermore, the increasing number of Halal certification logos leads to misunderstanding and confusion for consumers (Tieman, 2015; Havinga, 2011). Because "a general rules of Islamic jurisprudence holds everything as Halal, unless stated otherwise (Wilson, 2014 p. 259)", a Muslim in Islamic countries perceives that he/she has sensible knowledge in Islam to discern Halal from non-Halal (Haram) products (Wilson, 2014). For that reason, rather than researching products or certifications, many consumers, especially those residing in Islamic countries, simply take for granted that products produced in their country conform to Halal principles (Campbell et al, 2011).

Advancement in information and communication technologies (ICTs) stimulates an increased effort to reduce information asymmetry for consumers by increasing transparency of product information, especially in specialty markets such as sustainability and health products (Graham \& Haarstad, 2014; Luna-reyes et al, 2014). The use of web or mobile applications (apps) as a 
resource for understanding product quality is associated with improved customer awareness of product qualities information, resulting in overall transparency in the marketplace and more informed purchasing decisions on the part of the consumer (Gleim et al, 2013; Luna-reyes et al, 2014). Still, the question remains as to whether making product information more available and accessible to consumers is actually useful and valuable to the consumer. Davis (1989) argues that the likelihood of consumers to adopt the ICT initiative is influenced by their perceptions of the technology usefulness and ease of use. We adopt Davis' (1989) position and define usefulness in this paper as the consumer's belief in the importance of online traceability to enhance assessment of product information, particularly related to product compliance to Halal principles.

This paper presents an exploratory study on the process by which Muslim consumers place values on transparency efforts pertinent to product compliance to Halal principles. The transparency initiative in this study refers to online traceability, which is the capability to trace and verify, through the web and mobile apps, that the product as described on the package and label is produced following Halal practices and processes. This paper focuses on understanding traceability at the consumer's level; the extent to which a consumer could trace and verify that a Halal food and beverages product is $100 \%$ Halal in terms of being produced following Sharia principles. The paper focuses at the consumer level given the importance of empowering consumers to make informed choices in bringing Halal from niche to the mainstream market (Wilson, 2012). As pointed out by the CEO of International Halal Integrity Alliance, Malaysia, "rather than trying to indoctrinate a single standard, it would be more practical to develop a system where consumers are empowered to make an informed decision. (Wilson, 2012 p. 290)"

We are in agreement with Wilson (2014a, b, c) argument for the need to understand Halal branding as more than just atomizing and judging product's ingredients but more as the way to 
deliver values and knowledge to consumers. We posit that transparency through mobile and web apps is one way to realize the aforementioned vision. While some studies attest the increasing trend in Muslims to use web-mediated information to make decisions (Ibrahim, Noor \& Mehad, 2009), this paper enriches the discussion by addressing two research questions: a) Do Muslim consumers value additional information or the ability to verify product compliance with Halal principles mediated via web or mobile apps? and b) What are the determinants of consumer perception of the usefulness of additional information or the ability to verify product compliance with Halal principles mediated via web or mobile apps? Web or mobile apps to trace Halal product is a novelty in Indonesia, the capability was just launched in 2014 by the Assessment Institute for Foods, Drugs and Cosmetics, the Indonesian Council of Ulama (AIDC ICU/LP POM MUI ${ }^{1}$ who released a mobile app called Halal MUI to help consumers in Indonesia search and trace product compliance to Halal principles (Hakim, 2015). The proliferation of such web/mobile apps and tools brings about questions regarding consumer's perceptions of the usefulness of the ability to verify product compliance with Halal principles.

\section{Literature Review}

\subsection{Trust in Halal Product Information}

Perfect information is a fundamental assumption underlying the economic theory of competition (Stigler, 1957). Unfortunately, assumption of perfect information in free markets is not guaranteed to be reliable. Consumers are often at a disadvantage in trading relationships due to asymmetrical product quality information. Information regarding product quality is sometimes not transparent to the consumer (Darby \& Karni, 1973; Nelson, 1970). Consequently, consumer trust in product information is crucial in market transactions, particularly when the product

\footnotetext{
${ }^{1}$ http://www.austrade.gov.au/ArticleDocuments/1418/IABW_PFB_LPPOM-MUI.pdf.aspx
} 
attributes are not observable (Arora, 2006). Trust in product information is an important tool for consumer purchase decisions, including for Halal products (Lada, Tanakinjal \& Amin, 2009).

In general, researchers posit that the production of trust emerges from three mechanisms, namely: relational, calculative and institutional (Rousseau et al, 1998). Relational trust occurs from repeated relationships between trustee and trustor either at a personal or organizational level (Rousseau et al, 1998). Relational trust is the most favored trust mechanism for Halal consumers (Campbell et al, 2011). Consumers of Halal products prefer to buy from local producers with whom the consumers have forgoing and frequent interactions (Verbeke et al, 2013; van der Spiegel et al, 2012). Muslim consumers are even willing to pay premium for products offered by local producers rather than buying in a supermarket (Verbeke et al, 2013; van der Spiegel et al, 2012). The recurrent interactions serve as assurance of the local producers' compliance with Halal principles (Campbell et al, 2011).

However, it becomes more challenging for consumers to rely solely on relational trust when the supply chain lengthens and consequently, the strength of interpersonal trust diminishes or is absent entirely (Campbell et al, 2011, Starobin \& Weinthal, 2010). In such cases, interpersonal trust is replaced or complemented with institution-based trust (McKnight \& Chervany, 2001). With institution-based trust, the relationships between trustee and trustor are strengthened and regulated by institutional framework such as regulations (McKnight \& Chervany, 2001; Rousseau et al, 1998). Regulations and institutions afford favorable conditions for both trustee and trustor because they provide assurance of security and control over risks (McKnight \& Chervany, 2001; Lewis \& Weigert, 1985; Zucker, 1986). For instance, trust in institutions and organizations increase consumers' confidence about food safety (de Jong et al, 2008). 
In the case of Halal products, institution-based trust emerges in the form of Halal certification bodies and logos. The existence of Halal logos on product packaging signifies the producer's compliance with Halal principles, verified by a Halal certification body (Campbell et al, 2011). Unfortunately, institutional trust through certification logos and standards is currently challenged with existence of a large numbers of Halal certification bodies and the lack of harmonization among their certification processes (Tieman, 2015). With over 400 Halal certification bodies as of 2014, and each having its own certification process, it is difficult for consumers to trust that products are actually what they claim to be (van der Spiegel et al, 2012). Furthermore, the increase in certification bodies has incited dishonest use of Halal logos and certifications (Hava, 2009; van der Spiegel et al, 2012). For instance, Midamar, a company in Minnesota, U.S., falsified packaging labels and sold beef products to Malaysia and Indonesia that did not meet Halal principles (Flynn, 2016). The lengthening and complexity of global supply chains, the use of various ingredients from various sources, and manufacturing plants that produce both Halal and non-Halal products also contribute to diminished value of institutional trust through Halal logos and certifications (van der Spiegel et al, 2012).

\subsection{Information and Communication Technologies (ICTs) and Transparency Efforts to}

\section{Support Smart Consumption}

Recently, the advancement of ICTs has facilitated the creation of a novel approach to product traceability. These technologies integrate consumer-driven social computing systems and mobile technology-mediated ethical consumption tools (Luna-Reyes et al, 2014). Technologies, such as goodguide.com, have the potential to facilitate more informed purchasing decisions. In 2011, the U.S. government initiated and promoted the use of information disclosure as a regulatory approach, coined as Smart Disclosure (Sunstein, 2011). Smart Disclosure is "the act of making 
data more readily available and accessible, both to consumers directly and to innovators who can use it to build tools that help consumers make better informed decisions, and create more transparent, efficient market for goods and services" (Executive Office of the President National Science and Technology Council, 2013). The basic premise of Smart Disclosure is giving more power to the general public by transferring control of personal data from the hands of corporate interests to the public (Cobb, 2012).

The potential of Smart Disclosure also fits very well with the increasing trend of product traceability (Zhang et al, 2016). The combined technological approach—consumer-driven social computing systems, mobile technology, and smart data disclosure-enables alteration of consumer choice architecture, potentially enhancing the utility of certification, including Halal certification, to help consumers make choices that fit with their belief systems and values through traceable product information (Zhang et al, 2016). Consumer comprehension of product quality can be enhanced through the ability to trace product information using web or mobile applications (Gleim et al, 2013; Luna-reyes et al, 2014). The same premise applies to product compliance to Halal principles. From a rationalistic point of view, consumers who are predisposed to needing additional information to verify and substantiate their purchasing decisions with their beliefs and norms will place more value on the usefulness of product compliance traceability to track compliance to standards, including Halal standards. Certain determinants, as presented in the next section, could influence the consumer's perception of traceability options as useful. 


\subsection{Consumer Perceptions on the Usefulness of Online Traceability: Hypothesis}

\section{Development}

Studies have found that Muslim consumers search, use and rely on online information to help them make decisions (Karim \& Hazmi, 2005; Al-shamaileh, Sutcliffe \& Angeli, 2011; WanChick, 2015; Ibrahim, Noor \& Mehad, 2009). Likewise, Muslim consumers are demanding more disclosure of product information to ensure their purchasing decisions (Razzaque \& Chaudry, 2012). Conceivably, providing Muslim consumers with the ability to trace product compliance with Halal principles through web and mobile apps augments their trust in the product and potentially helps the consumer to make a purchasing decision. As argued by Zhang et al (2016), there remains the empirical question as to what extent and what factors determine consumer perceptions on the importance and usefulness of having information generated from the web or mobile-based traceability apps.

People have varying dispositions to trust in exchange relationships including in purchasing decisions (Zhang et al, 2016). Some individuals demonstrate lower tendencies to trust, while others naturally have a greater inclination to trust (Mayer et al, 1995). The formation of an individual's trusting beliefs, intentions, and behaviors are significantly influenced by the individual's disposition to trust (Grabner-Kräuter \& Kaluscha, 2003). For instance, trust in a vendor in an online environment is influenced by the consumer's disposition to trust (Gefen, 2000). The Muslim consumer's disposition to trust in the Halal logo is affected by the circumstances of daily life (Campbell et al, 2011). Muslim consumers tend to take for granted that products are Halal in an environment where the dominant population is Muslim (BergeaudBlackler, 2007; Campbell et al, 2011). In such an environment, consumers arguably have greater belief in the Halal certification body, so consumers will have less incentive to value the ability to 
trace a product's compliance to Halal principles. Consequently, the consumer's belief in a Halal certification body significantly but negatively influences their perceptions of the usefulness of the ability to verify product compliance with Halal principles.

\section{$\mathrm{H}_{1}$ : A general belief in Halal certification bodies significantly but negatively influences consumer perceptions of the usefulness of the ability to verify product compliance with Halal principles via web or mobile apps.}

The Halal logo and certification conveys product quality that is not only informed by dietary laws and religious values but also conformance to a country's legislative requirements (van der Spiegel et al, 2012, Verbeke et al, 2013). Although the position of food safety regulation within Halal requirements is not yet clear (Demirci et al, in Press), it is argued that consumption of Halal products signifies not only adherence to the religious belief but also entails consumption of healthy and high-quality products (Atalan-Helicke, 2015). Bonne and Verbeke (2006) claim that Halal processing of meat produces healthier meat. Thus, Halal not only attracts consumers as a result of religious beliefs, but also consumers who focus on healthy and high-quality products (van Warden \& van Dalen, 2010). A survey of Halal consumers in Malaysia reveals that the majority of the respondents cited health benefits as a factor in choosing to consume Halal products (Mohamed et al, 2008; Bonne \& Verbeke, 2006). Health-conscious Muslim consumers will strive to search for more information to ascertain product value. Hence, these consumers will be more likely to perceive having the ability to verify Halal product information as useful. $\mathrm{H}_{2}$ : Health conscious consumers are more likely to value the usefulness of the ability to verify
product compliance with Halal principles via web or mobile apps.

Fragmentation of Halal certification bodies induces competitiveness among them (AtalanHelicke, 2015). Such situations increase the number of abstruse promises and claims that some certifications are "even more Halal" than others (Campbell et al, 2011). This creates a situation known as "greenwashing" in the sustainability product market (Makower, 2010). As a way to 
differentiate themselves from numerous competitors, certification bodies are forced to develop a reputation as promoter of stricter "Halal rules" (Lever \& Miele, 2012). It is safe to argue that a higher reputation of Halal certification agencies will influence consumer perceptions of the usefulness of the ability to verify product compliance with Halal principles. One way to demonstrate a good reputation is relying on a third-party organization to offer endorsement, resulting in a renewal of consumer trust (Albersmeier et al, 2009). As such, self-declared Halal certification bodies may be associated with conflicts of interests and untrustworthiness, giving rise to lower consumer trust. For instance, Islamic Services of America (ISA), a globally recognized Halal certifying body founded in 1975 in the U.S., was found guilty and fined for supporting the sale of one of the founder's false Halal product sales (Salama, 2016).

Consequently, consumers will put greater value on the ability to verify product compliance with Halal information if the product is certified by a self-declared certification body.

$\mathrm{H}_{3}$ : The reputation of a Halal certification body significantly but negatively influences consumer values of the usefulness of the ability to verify product compliance with Halal principles via web or mobile apps.

$\mathrm{H}_{4}$ : Self-declared Halal certification significantly and positively influences consumer values of the usefulness of the ability to verify product compliance with Halal principles via web or mobile apps

90 percent of products marketed as Islamic brands are usually owned by Multinational

Corporations (MNCs) such as Nestle, Unilever and others who have predominantly non-Muslim shareholders (Alserhan, 2010). The MNCs have the outstanding branding skills and resources to market products as Islamic brand based mostly on their target consumer (Alserhan, 2010). A well-known product brand has a profound impact on the perception of consumers buying the product (Fan, 2005). Given that brand names increase consumer's preference toward the Halal product (Rosa, Riquelme \& Abdelaziz, 2014), it is plausible that consumers take the Halal logo for granted if the product brand is well known to them. Hence, consumers who value product 
brands will have less incentive to consider the ability to verify product compliance with Halal principles as important. Likewise, company activities, performances and prospects reflect consumer perceptions of the company reputation (Fombrun, 2000). For instance, consumers impart positively to a socially responsible image of a firm (Fan, 2005). A company's reputation is a crucial antecedent to trust (Gefen, 2000) in which trustees with good reputations are deemed more trustworthy (McKnight et al., 1998). Thus, consumers might be less likely to value the usefulness of the ability to verify product compliance with Halal principles if the consumers perceived that the company had a good reputation. Accordingly, based on the above-mentioned review of the literature, we posit the following hypothesis:

$\mathrm{H}_{5}$ : A company's reputation significantly but negatively influences the consumer's value of the usefulness of the ability to verify product compliance with Halal principles via web or mobile apps.

$\mathrm{H}_{6}$ : Brand reputation significantly but negatively influences the consumer's value of the usefulness of the ability to verify product compliance with Halal principles via web or mobile apps.

Figure 1 depicts the preliminary model identified from the above-mentioned literature review.

\section{--- Insert Figure 1. Preliminary Model here ---}

\section{Research Methodology}

In this section of the paper we introduce the methods and procedures followed to test the hypotheses introduced in the previous section.

In total, 160 usable questionnaire were obtained from a large Muslim University in Indonesia through a survey 


\subsection{Data Collection}

Data for this study was collected using a questionnaire distributed to a large Muslim University in Indonesia in March 2015 with a total of 188 responses received. All of the respondents were Muslim. To provide a context for the research, a decision-making assignment based on Halal product-purchasing decisions was distributed to all respondents before they were asked to answer the survey. The questionnaire was developed initially in Indonesian and it was translated to English. After data cleaning, we excluded responses with greater than $10 \%$ missing values. In the end, 160 observations were used for the analysis.

\subsection{Variable development and measurement}

Our description and measurement of the dependent and independent variables in this study is as follows.

\section{a. Dependent Variable}

The dependent variable is the online ability to trace product compliance to Halal principles and practice. This is a composite variable consisting of 4 sub-variables that measure consumer perceptions of the usefulness of the ability to verify Halal compliance through web or mobile apps and the ability to verify by linking to a company/government/ NGO website describing the organization's Halal practice. Chronbach's alpha is used to test the reliability of the measurement of this variable and the result is 70.84 which is above the threshold of 0.70 , indicating strong reliability.

\section{b. Independent Variables}

There are 6 independent variables of interest in this research and the description is as follows. 
- Disposition to trust Halal certification bodies. This variable measures the tendency of respondents to trust certification agencies regardless of other reasons. This variable signifies a consumer's disposition to trust the certification bodies.

- Consumer value of product health effects. This variable measures the extent to which the respondents value a healthy lifestyle in regard to product consumption.

- Reputation of certification bodies. This variable measures the importance of the reputation of Halal certification bodies in contrast to consumer research to acquire more information about the logo/label.

- Self-declared Halal companies. This variable measures the importance of self-proclaimed Halal certification bodies in contrast to consumer research to acquire more information about the logo/label.

- Company reputation. This variables measures the importance of a company's reputation in comparison to the certification information.

- Brand reputation. This variable measures the importance of a product brand in comparison to the certification information.

\section{Results and Findings}

\subsection{The Usefulness of Online Traceability to Verify Halal Product Information in Indonesia}

In this study, we measure online traceability in two forms. First, we measure online traceability as the importance and usefulness of having additional information to verify and ensure product compliance to Halal practices and processes. Second, online traceability is measured as having a link to a company, government, or NGO website describing and verifying product compliance to Halal practices and processes. The survey results indicate that Muslim consumers appreciate having additional information or links to an external website to trace and 
verify product compliance: an average of $65 \%$ of respondents agree, $30 \%$ of respondents expressing a neutral stance, and only $5 \%$ of respondents disagree. Comparing the two forms, results show that Muslim consumers were more appreciative of additional information (on average, $80 \%$ of respondents agree on the usefulness) than to have a link to an external website (on average, $54 \%$ of respondents agree on the usefulness) to trace and verify compliance to Halal practices and processes. Interestingly, the number of respondents who took a neutral position when measuring the usefulness of online traceability through links to external websites is higher. The respondent are less convinced of the usefulness of a link to an external website compared to having additional information through the web or mobile apps with regard to compliance to Halal practices and processes. Given that purchasing decisions are a complex undertaking and consumers have limited time to make decisions (Park, Iyer \& Smith, 1989), the consumer's value links to external website less because they do not have time to click the link and browse through the site.

Table 1. The Usefulness of Online Traceability of Halal Product Information

\begin{tabular}{|c|c|c|c|}
\hline Online Traceability Measurement & Agree & Neutral & Disagree \\
\hline $\begin{array}{l}\text { It is very important for me to have additional information about Halal } \\
\text { practice and process conducted by the companies in producing the product }\end{array}$ & $82.0 \%$ & $14.0 \%$ & $4.0 \%$ \\
\hline $\begin{array}{l}\text { It is very useful for me to be able to verify to ensure that a product and its } \\
\text { production process complies to Halal practice and process through web or } \\
\text { mobile applications }\end{array}$ & $79.0 \%$ & $18.0 \%$ & $3.0 \%$ \\
\hline $\begin{array}{l}\text { Link to a company website describing the company's Halal practice and } \\
\text { process is very important }\end{array}$ & $56.0 \%$ & $40.0 \%$ & $4.0 \%$ \\
\hline $\begin{array}{l}\text { Link to a government website verifying that a product truly complies to } \\
\text { Halal principle is very important }\end{array}$ & $60.0 \%$ & $34.0 \%$ & $6.0 \%$ \\
\hline $\begin{array}{l}\text { Link to a particular NGOs website verifying that a product truly complies to } \\
\text { Halal principle is very important }\end{array}$ & $48.0 \%$ & $46.0 \%$ & $6.0 \%$ \\
\hline
\end{tabular}

When only comparing the Muslim consumer's perception on the usefulness of having a link to an external website to trace and verify Halal compliance, the results indicate decreasing trends of agreement depending on the organizations. The majority $(60 \%)$ of respondents agree that links 
to government websites to verify product compliance is useful. The agreement decreases by $12 \%$ when the link to verify Halal compliance changes from government to a particular NGO website. These results may suggest that Muslim consumers in Indonesia have a different level of trust toward the government versus NGOs. As shown in the results, Muslim consumers in Indonesia perceived NGOs as less trustworthy than the government when it comes to providing assurance regarding product compliance to Halal principles. This result is intriguing given that based on the Edelman 2016 trust barometer ${ }^{2}$, in general, trust in NGOs is significantly higher than trust in the government. In fact, the result of the 2012 Edelman trust barometer ${ }^{3}$ demonstrates that trust in NGOs in Indonesia (53\%) is higher than trust in government (40\%).

Plausibly, this suggests that the value of trust in government or NGOs for Indonesian people depends on the policy issues at hand. With regard to religious-based food policy issues, consumers trust the credibility of information from the government more than the information from NGOs. The results also signify that respondents are more undecided when it comes to perceived usefulness of the ability to trace and verify Halal compliance through a link to company websites describing Halal practices: $56 \%$ of respondents agree while $40 \%$ remained neutral. These results are also intriguing given that based on the Edelman 2012 trust barometer survey, consumers in Indonesia consider business to be the most trustworthy institution as compared to government and NGOs. Again, we posit that different policy issues drive how the respondents perceived trust in institutions in Indonesia. Given the differences in responses, we discuss factors that determine Muslim consumers in Indonesia perceiving usefulness of online traceability in the next section.

\footnotetext{
${ }^{2}$ https://www.ibe.org.uk/userassets/survey $\% 20$ summaries $/$ ibe $^{2} \% 20$ summary $\% 20$ edelman $\% 20$ trust $\% 20$ barometer $\% 202016$.pdf

${ }^{3}$ http://www.edelman.com/insights/intellectual-property/2012-edelman-trust-barometer/about-trust/global-results/
} 


\subsection{Determinants of Consumer Appreciation of Online Traceability to Verify Halal Product}

\section{Information}

The results show that consumers who generally believe Halal certification agencies and who are concerned with the health values of the products are more likely to appreciate the ability to trace product compliance to Halal practices and processes at 0.95 confidence level with $\mathrm{t}_{\text {value }}$ of 2.18 and coefficient estimates of 0.28 . This result indicates that Muslim consumer appreciation of online traceability to verify product compliance to Halal principles will increase by 0.28 if their values of the health benefits of the products increase by one degree. Muslim consumer disposition to trust Halal certification bodies emerge as a significant predictor of the consumer's perception of the value of online traceability to verify product compliance to Halal principles at 0.99 confidence level with $t_{\text {value }}$ of 3.12 and coefficient estimates of 0.409 . This result augments the finding from the Edelman trust barometer (Edelman, 2015) which indicates that Indonesian people have a high disposition to trust. Thus, Muslim consumers in Indonesia have a tendency to trust information provided by the Halal certification bodies and logos regardless of other reasons.

The rest of the variables measure the influence of reputation on consumer perception of the value of online traceability. We measure reputation from three perspectives: company, brand, and certification bodies. The results show that Muslim consumers in Indonesia place greater trust on reputable certification bodies. The results indicate that certification from reputable certification bodies is positive and significantly influences consumer perceptions on the value of online traceability to verify product compliance to Halal practices and processes at 0.99 confidence level with $t_{\text {value }}$ of 3.32 and coefficient estimates of 0.446 . 
Table 2. Regression Results

\begin{tabular}{lrrrr}
\hline Predictors & \multicolumn{1}{c}{$\beta$} & \multicolumn{1}{l}{ BETA } & \multicolumn{1}{l}{$S E$} & \multicolumn{1}{l}{$t$} \\
\hline Disposition to trust Halal certification bodies & 0.409 & 0.215 & 0.131 & 3.12 \\
Consumer's value on health effects of products & 0.280 & 0.162 & 0.128 & 2.18 \\
Certification label from reputable certification bodies & 0.446 & 0.261 & 0.138 & 3.23 \\
Company's self-declared Halal & 0.382 & 0.192 & 0.137 & 2.79 \\
Company's reputation & -0.302 & -0.203 & 0.125 & -2.40 \\
Brand Reputation & 0.087 & 0.058 & 0.137 & 0.64 \\
Constant & -2.905 & - & 0.658 & -4.41 \\
\hline $\mathrm{N}$ & & & & 160 \\
$\mathrm{~F}(6,153)$ & & & & \\
$\mathrm{R} 2$ & & & & $25.8 \%$ \\
\hline
\end{tabular}

We also found the results support the hypothesis with regard to the influence of a company's reputation. The results indicate that a company's self-declared Halal guarantee is positive and significant in influencing consumer perception of the usefulness of online traceability to verify product compliance to Halal practices and processes at 0.95 confidence level with $t_{\text {value }}$ of 2.79 and coefficient estimates of 0.382 . As expected, consumer suspicion of the company practices increases with the self-declared Halal label which then escalated the usefulness of the ability to trace product information. The results also show that company reputation is significant but negatively influences consumer value of online traceability to trace product compliance to Halal principles. The negative result demonstrates the significant power of a company's reputation. Muslim consumers in Indonesia tend to relax their perceptions of the usefulness of the ability to trace product compliance to Halal practices and processes if the product is produced by a reputable company. This is plausibly because, as argued by Cretu \& Brodie (2007), company's reputation influences consumer's perceptions of products quality and customer loyalty. Thus, Muslim consumers' belief on product quality augments the inherent assumption that the products produced in Islamic countries conform to Halal principles. As such, consumers have less incentive to verify products through web or mobile apps when they perceive that the company producing the product has high reputation. Finally, the regression results show that brand 
reputation is not a significant predictor of consumer perceptions of the usefulness of online traceability to trace and verify product compliance to Halal practices and processes.

\section{Discussions}

In summary, this study suggests that Muslim consumers in Indonesia value the usefulness of online traceability of product information. Their perceptions of usefulness are influenced by three main predictors.

\subsection{Indonesian Muslim Consumer's Healthy Lifestyles}

Our findings indicate that Muslim consumers who embrace healthy lifestyles are more likely to value online traceability to trace and verify product compliance to Halal principles and practices. Consumption of Halal processed food not only signifies adherence to Islamic principles but also adherence to a healthy lifestyle that includes foods that are healthy and produced using high-quality production processes (Campbell et al, 2011; Atalan-Helicke, 2015). This is because Halal certification implicitly conveys information about food safety aspects and product quality (Demirci, Soon \& Wallace, 2016), in the sense that product processing complies with both the Islamic principles and the state regulations regarding food processing and consumption (van der Spiegel et al, 2012, Verbeke et al, 2013). Bonne and Verbeke (2006) even go so far as to say that Halal meat processing has the potential to reduce foodborne illness because it produces healthier meat.

Consequently, Muslim consumers who are mindful about maintaining healthy lifestyles are very ardent in monitoring information for the benefit of themselves, but more importantly to share the information with others who follow similar lifestyles (Yeh \& Chen, 2011). Thus, they are more likely to embrace the ability to trace product compliance to Halal principles in order to 
satisfy their health-related values, because searching and sharing of information become an integral part of their everyday lifestyle (Yeh \& Chen, 2011). The more the consumers value a healthy lifestyle, the more likely they are to pursue additional information to ensure that their consumption supports their values. This result corresponds to Unilever's "World Menu Report" which revealed that lack of knowledge regarding the recommended daily allowance for food is a major challenge for consumers when choosing healthier dishes, including in Indonesia. As result, consumers were increasingly demanding for more information about their food (Unilever Food Solutions, 2013).

Our findings thus impart implications for food safety policies through the provision of trustworthy information and tools to inform consumers and consequently, enable them to choose and consume healthy products. Such capability is crucial for Indonesia in particular given that: a) a report from the World Health Organization (WHO) in 2012 shows that $40 \%$ deaths in Indonesia were associated with diet-related diseases such as stroke (21\%), heart disease (12\%), and diabetes $(7 \%)^{4} ;$ b) according to the Minister of Social Affairs, only $4.9 \%$ of consumers in Indonesia are knowledgeable about safe and healthy food (Novia, 2016); and c) guideline number thirteen of the Indonesian Dietary Guidelines of 1995 from the Ministry of Health specifies that consumers "must read the labels of packaged foods." However, this is not followed (Usfar \& Fahmida, 2011), presumably due to limited knowledge regarding how to thoroughly read labels. We thus posit that smart food safety policy through the presentation of information and provision of tools to help consumers understand the meaning and consequences of their consumption decisions will influence the consumers' consumption decisions. A smart food safety policy could leverage on the degree of trust that consumers in Indonesia place on Halal

\footnotetext{
${ }^{4}$ http://www.cdc.gov/globalhealth/countries/indonesia/
} 
practices and processes. On the other hand, given the disconnection between food regulation and Halal certification (Demirci et al, in Press), policymakers in Indonesia should pay close attention to the integration of food safety regulation with Halal requirements.

\subsection{Indonesian Muslim Consumers Disposition to Trust and the Value of Reputation}

Based on the Edelman global trust barometer for 2015, Indonesian people have a tendency and disposition toward trust. Indonesia ranks among the top ten trusting countries for 2012 to 2015 for both the informed public and the general population (Edelman, 2015) 5 . Our findings demonstrate that a strong disposition of Muslim consumers in Indonesia to trust Halal certification bodies significantly influences their perceptions of the usefulness of online traceability to trace and verify product compliance to Halal principles. This finding is intriguing considering that if Muslim consumers in Indonesia have a high disposition to trust certification bodies as indicated by Edelman survey, then reasonably they do not need online traceability to verify product compliance. Instead, they should be predisposed to trust the product given that the Halal logo is printed on the packaging.

In spite of Indonesian consumers' disposition to trust certification bodies, they still find value in online traceability tools because they are aware that not all products displaying the Halal logo are processed according to Halal principles in the strictest sense. However, Muslim consumers presume that certification bodies are impeccable because the stewards of the Halal standard are reputable Islam clerics (Indonesian Council of Ulama / MUI). For that reason, consumers assume that any case of Halal product adulteration is due to the evil doing of the producers. Hence, despite the consumer's disposition to trust certification bodies, they still feel the need to have online traceability to verify product compliance. Our preliminary thesis thus

\footnotetext{
${ }^{5}$ http://www.edelman.com/insights/intellectual-property/2015-edelman-trust-barometer/global-results/
} 
suggests a finding contrary to the Bergeaud-Blackler (2007) and Campbell et al, (2011) assertion that in an environment where the dominant population is Muslim, such as in Indonesia, the general population always assumes that products must be Halal.

Our findings also indicate the positive and significant relationship between the reputation of certification bodies and consumer value of online traceability. This result is intriguing because it demonstrates that reputable certification bodies are associated with increased consumerperceived value and usefulness of product compliance traceability. Plausibly, there is supposed to be an inverse relationship; meaning, if consumers perceived that a certification body's reputation was sufficient to ensure that the product is produced following Halal practices and processes, then supposedly the consumers will not have a need for online traceability. This finding reinforces our above-mentioned thesis regarding relationships between disposition to trust and the usefulness of online traceability.

The finding provides suggestive evidence of the Muslim consumer's concern about fragmentation of Halal certification and logos and consumer wariness regarding producer conduct. We argue that Muslim consumers in Indonesia have a high disposition to trust and place high value on the reputation of certification bodies, but they are less certain about the trustworthiness of the producers. As result, although the reputation of Halal certification bodies is important to consumers, they still feel the need to verify compliance to Halal practices and processes. Hence, even if the consumer is disposed to trust certification bodies, and a given certification body has a strong reputation, the consumer values the ability to verify and trace product compliance to Halal principles, due to consumer concerns about the producer's conduct. Our assertion is supported by the fact that we found company reputation to be a significant but negative predictor of the usefulness of online traceability. The negative sign indicates that 
reputable companies are perceived to be trustworthy by consumers with regard to adherence to Halal principles and as result, consumers become less inclined to place great value on the availability of online traceability to verify product compliance.

Our findings thus impart practical implications in product marketing. The findings demonstrate that Muslim consumers in Indonesia value online traceability options, regard the reputation of certification bodies and company reputation, and they are likely to trust certification bodies. Consequently, provision of mobile or web applications that recognize the reputation of the certification bodies and the company could be an effective marketing tool for product differentiation and to stimulate consumer purchasing decisions.

\section{Concluding Remarks}

Provision of information to help consumers making an informed decision which affords the power back at the hand of the consumers is one of the markers of the Halal industry movement from niche to the mainstream market (Wilson, 2014a, 2014b, \& 2014c). Democratization of information through the web allows consumers to take more interest in their consumption by, among other things, being more prudent in searching for more information about the product. The focus of Halal compliance in terms of atomizing and judging product's ingredients will no longer be sufficient (Wilson, 2014a, 2014b, \& 2014c). The marketing activities of Halal should focus on delivering values through the provision of knowledge and service to the consumers (Wilson, 2014a, 2014b, \& 2014c). The intention of this paper has been to evaluate consumer perceptions of the usefulness of online traceability to verify product compliance to Halal principles in Indonesia. The current study suggests that Muslim consumers in Indonesia perceived the ability to trace product compliance to Halal principles as useful and important. The Muslim consumer's perception of the usefulness of online traceability is influenced by three 
main factors: the consumer's disposition to trust, tendency toward a healthy lifestyle, and the reputation of the certification bodies and the company.

The findings from this study impart both practical and policy implications. On a practical note, the findings highlight the consumer's value of the provision of web and mobile apps to help them make purchasing decisions. Due to the tendency toward risk aversion, Halal-conscious consumers have inclination to seek high involvement and understand the products better (Wilson $\&$ Liu, 2010; 2011). For that reason, combining the availability of traceability tools with alteration of consumer choice architecture through the disclosure of information could provide an effective marketing medium. Likewise, online traceability options through web and mobile apps are valuable to support the much needed smart food safety policy in Indonesia and other developing countries. Disclosure policies through web and mobile apps could facilitate improvement in consumer understanding of product safety and consumption that could potentially diminish the possibilities of foodborne illness. Another point worth considering, while we found that consumers place different value on the usefulness of linking to external websites as compare to having additional information, we did not consider this difference in our regression analysis. Future research could ascertain whether the determinants differ between the different types of online traceability efforts. As a final note, this study obtains survey data from students enrolled in Muslim university in Indonesia which arguably represent a homogeneous sample. As limitation, this study may not be applicable to a more general population. For that reason, further research is needed to ascertain the generalizability of this study's findings.

\section{Acknowledgments}

This work was partially supported by the Directorate General of Higher Education (DIKTI) of Indonesia and the University of Muhammadiyah Malang (UMM). Any opinions, findings, and conclusions or recommendations expressed in this material are those of the authors and do not necessarily reflect the views of the DIKTI and UMM.

\section{References}


Albersmeier, F., Schulze, H., Jahn, G., \& Spiller, A. (2009). The reliability of third-party certification in the food chain: From checklists to risk-oriented auditing. Food Control, vol. 20 no.10, pp. 927-935. http://doi.org/10.1016/j.foodcont.2009.01.010

Alserhan, B. A. (2010). On Islamic branding: brands as good deeds. Journal of Islamic Marketing, vol. 1 no. 2, pp. 101-106. http://doi.org/10.1108/17590831011055842

Al-shamaileh, O., Sutcliffe, A., \& Angeli, A. D. (2011). The Effect of Religious Identity on User Judgment of Website Quality. In P. Campos, N. Graham, J. Jorge, N. Nunes, P. Palanque, \& M. Winckler (Eds.), Human-Computer Interaction - INTERACT. Springer Berlin Heidelberg, pp. 620-623. Retrieved from http://link.springer.com/chapter/10.1007/978-3642-23768-3_97

Arora, R. (2006). Product positioning based on search, experience and credence attributes using conjoint analysis. Journal of Product \& Brand Management, vol. 15 no. 5, pp. 285-292. http://doi.org/10.1108/10610420610685695

Atalan-Helicke, N. (2015). The halal paradox: negotiating identity, religious values, and genetically engineered food in Turkey. Agriculture and Human Values, vol. 32 no. 4, pp. 663-674. http://doi.org/10.1007/s10460-015-9585-z

Barometer, E. T. (2016). Edelman trust barometer, available at http://www.edelman.com/insights/intellectual-property/2015-edelman-trust-barometer/ (accessed by April 10, 2016).

Bergeaud-Blackler, F. (2007). New Challenges for Islamic Ritual Slaughter: A European Perspective. Journal of Ethnic and Migration Studies, vol. 33 no. 6, pp. 965-980. http://doi.org/10.1080/13691830701432871

Bonne, K., \& Verbeke, W. (2006). Muslim consumer's motivations towards meat consumption in Belgium: qualitative exploratory insights from means-end chain analysis. Anthropology of Food, no.5. Retrieved from http://aof.revues.org/90

Campbell, H., Murcott, A., \& MacKenzie, A. (2010). Kosher in New York City, halal in Aquitaine: challenging the relationship between neoliberalism and food auditing. Agriculture and Human Values, vol. 28 no.1, pp. 67-79. http://doi.org/10.1007/s10460010-9260-3

Cobb, J. (2012). Smart disclosure: Innovation in personal data, available at http://www.spruceadvisers.com/smart-disclosure-innovation-in-personal-data/ (accessed by May 22, 2016).

Cretu, A. E., \& Brodie, R. J. (2007). The influence of brand image and company reputation where manufacturers market to small firms: A customer value perspective. Industrial Marketing Management, 36(2), 230-240. http://doi.org/10.1016/j.indmarman.2005.08.013

Darby, M. R., \& Karni, E. (1973). Free Competition and the Optimal Amount of Fraud. The Journal of Law \& Economics, vol. 16 no. 1, pp. 67-88.

Davis, F. D. (1989). Perceived Usefulness, Perceived Ease of Use, and User Acceptance of Information Technology. MIS Quarterly, vol. 13 no. 3, pp. 319-340. http://doi.org/10.2307/249008

de Jonge, J., van Trijp, J. C. M., van der Lans, I. A., Renes, R. J., \& Frewer, L. J. (2008). How trust in institutions and organizations builds general consumer confidence in the safety of 
food: A decomposition of effects. Appetite, vol. 51 no. 2, pp. 311-317. http://doi.org/10.1016/j.appet.2008.03.008

Demirci, M. N., Soon, J. M., \& Wallace, C. A. (In Press). Positioning food safety in Halal assurance. Food Control. http://doi.org/10.1016/j.foodcont.2016.05.059

Edelman, R. (2015). Edelman trust barometer 2015 (Technical Report). http://www.edelman.com/insights/intellectual-property/2016-edelman-trust-barometer/.

Eisenhardt, K. M. (1989). Agency theory: An assessment and review. Academy of Management Review, vol. 14 no. 1, pp. 57-74.

Executive Office of the President National Science and Technology Council. (2013). Smart Disclosure and Consumer Decision Making: Report of the Task Force on Smart Disclosure. Washington DC: National Science and Technology Council.

Fan, Y. (2005). Ethical branding and corporate reputation. Corporate Communications: An International Journal, vol. 10 no. 4, pp. 341-350. http://doi.org/10.1108/13563280510630133

Flynn, D. (2016). Sentencing in Halal food case continued to Feb. 25. Food Safety News, February 6. Retrieved from http://www.foodsafetynews.com/2016/02/sentencing-ofwilliam-b-aossey-jr-continued-to-feb-25/

Fombrun, C. (2000). The value to be found in corporate reputation. Financial Times, December 4 , p. 2.

Gefen, D. (2000). E-commerce: the role of familiarity and trust. Omega, vol. 28 no. 6, pp. $725-$ 737. http://doi.org/10.1016/S0305-0483(00)00021-9

Gleim, M. R., Smith, J. S., Andrews, D., \& Cronin Jr., J. J. (2013). Against the Green: A Multimethod Examination of the Barriers to Green Consumption. Journal of Retailing, vol. 89 no. 1, pp. 44-61. http://doi.org/10.1016/j.jretai.2012.10.001

Grabner-Kräuter, S., \& Kaluscha, E. A. (2003). Empirical research in on-line trust: a review and critical assessment. International Journal of Human-Computer Studies, vol. 58 no. 6, pp. 783-812. http://doi.org/10.1016/S1071-5819(03)00043-0

Graham, M., \& Haarstad, H. (2014). Transparency and Development: Ethical Consumption through Web 2.0 and the Internet of Things. In M. L. Smith, K. M. A. Reilly, \& Y. Benkler (Eds.), Open Development: Networked Innovations in International Development. MIT Press.

Hakim, L. (2015). Halal Certification in Indonesia. Event presentations presented at the IABW (Indonesia Australia Business Week) Presentation, Australia. Retrieved from http://www.austrade.gov.au/ArticleDocuments/1418/IABW_PFB_LPPOM-MUI.pdf.aspx

Hava, E. (2009). New organization to sort out rotten apples in European halal food market. Sundays Zaman (Turkish English Language Newspaper).

Havinga, T. (2010). Regulating Halal and Kosher Foods: Different Arrangements Between State, Industry and Religious Actors. Erasmus Law Review, vol. 3 no. 4, pp. 241-255.

Ibrahim, E. N. M., Noor, N. L. M., \& Mehad, S. (2009). Trust or distrust in the web-mediated information environment (W-MIE): A perspective of online Muslim users. Journal of Enterprise Information Management, vol. 22 no. 5, pp. 523-547. http://doi.org/10.1108/17410390910993527 
Karim, N. S. A., \& Hazmi, N. R. (2005). Assessing Islamic information quality on the Internet: A case of information about hadith. Malaysian Journal of Library and Information Science, vol. 10 no. 2, pp. 51-66.

Lada, S., Tanakinjal, G. H., \& Amin, H. (2009). Predicting intention to choose halal products using theory of reasoned action. International Journal of Islamic and Middle Eastern Finance and Management, vol. 2 no. 1, pp. 66-76. http://doi.org/10.1108/17538390910946276

Lever, J., \& Miele, M. (2012). The growth of halal meat markets in Europe: An exploration of the supply side theory of religion. Journal of Rural Studies, vol. 28 no. 4, pp. 528-537. http://doi.org/10.1016/j.jrurstud.2012.06.004

Lewis, J. D., \& Weigert, A. (1985). Trust as a Social Reality. Social Forces, vol. 63 no. 4, pp. 967-985. http://doi.org/10.1093/sf/63.4.967

Luna-Reyes, L. F., Zhang, J., Whitmore, A., Jarman, H., Picazo-Vela, S., Andersen, D. L., ... others. (2014). Full information product pricing: An information strategy for harnessing consumer choice to create a more sustainable world. Communications of the Association for Information Systems, vol. 34 no. 32, pp. 637-654.

Makower, J. (2010, November 1). Is TerraChoice Greenwashing?, available at https://www.greenbiz.com/blog/2010/11/01/terrachoice-greenwashing (Accessed June 6, 2016)

Mayer, R. C., Davis, J. H., \& Schoorman, F. D. (1995). An Integrative Model Of Organizational Trust. Academy of Management Review, vol. 20 no. 3, pp. 709-734. http://doi.org/10.5465/AMR.1995.9508080335

McKnight, D. H., \& Chervany, N. L. (2001). Trust and Distrust Definitions: One Bite at a Time. In R. Falcone, M. Singh, \& Y.-H. Tan (Eds.), Trust in Cyber-societies (pp. 27-54). Springer Berlin Heidelberg. Retrieved from http://link.springer.com/chapter/10.1007/3540-45547-7 3

McKnight, D. H., Cummings, L. L., \& Chervany, N. L. (1998). Initial Trust Formation in New Organizational Relationships. Academy of Management Review, vol. 23 no. 3, pp. 473-490. http://doi.org/10.5465/AMR.1998.926622

Mohamed, Z., Rezai, G., Shamsudin, M. N., \& Chiew, E. (2008). Halal logo and consumers' confidence: What are the important factors? Economic and Technology Management Review, vol. 3, pp. 37-45.

Nelson, P. (1970). Information and Consumer Behavior. Journal of Political Economy, vol. 78 no. 2, pp. 311-329.

Novia, D. R. M. N. (2016). Baru 4,9 Persen Konsumen Indonesia Paham Makanan Sehat. Republika Online. April 27. Retrieved from http://nasional.republika.co.id/berita/nasional/umum/16/04/27/o6alwu328-baru-49-persenkonsumen-indonesia-paham-makanan-sehat

Park, C. W., Iyer, E. S., \& Smith, D. C. (1989). The Effects of Situational Factors on In-Store Grocery Shopping Behavior: The Role of Store Environment and Time Available for Shopping. Journal of Consumer Research, vol. 15 no. 4, pp. 422-433. http://doi.org/10.1086/209182 
Razzaque, M. A., \& Chaudhry, S. N. (2013). Religiosity and Muslim consumers' decisionmaking process in a non-Muslim society. Journal of Islamic Marketing, vol. 4 no. 2, pp. 198-217. http://doi.org/10.1108/17590831311329313

Rios, R. E., Riquelme, H. E., \& Abdelaziz, Y. (2014). Do halal certification country of origin and brand name familiarity matter? Asia Pacific Journal of Marketing and Logistics, vol. 26 no. 5, pp. 665-686. http://doi.org/10.1108/APJML-03-2014-0046

Rousseau, D. M., Sitkin, S. B., Burt, R. S., \& Camerer, C. (1998). Not So Different After All: A Cross-Discipline View Of Trust. Academy of Management Review, vol. 23 no. 3, pp. 393404. http://doi.org/10.5465/AMR.1998.926617

Salama. (2016). USA: Midamar Founder Sentenced to 2 Years in Prison in Halal Meat Case. February 25. Retrieved from http://halalfocus.net/usa-midamar-founder-sentenced-to-2years-in-prison-in-halal-meat-case/

Starobin, S., \& Weinthal, E. (2010). The Search for Credible Information in Social and Environmental Global Governance: The Kosher Label. Business and Politics, vol. 12 no. 3, pp. 1 - 35. http://doi.org/10.2202/1469-3569.1322

Stigler, G. J. (1957). Perfect Competition, Historically Contemplated. Journal of Political Economy, vol. 65 no. 1, pp. 1-17.

Sunstein, C. R. (2011). Informing Consumers through Smart Disclosure. White House, Washington $D C$.

Tieman, M. (2015). Halal clusters. Journal of Islamic Marketing, vol. 6 no. 1, pp. 2-21. http://doi.org/10.1108/JIMA-05-2014-0034

Unilever Food Solutions. (2013). World menu report global research findings 2012. Unilever.

Usfar, A. A., \& Fahmida, U. (2011). Do Indonesians Follow Its Dietary Guidelines?: Evidence Related to Food Consumption, Healthy Lifestyle, and Nutritional Status Within the Period 2000-2010. Asia Pacific Journal of Clinical Nutrition, vol. 20 no. 3, pp. 484-493.

van der Spiegel, M., van der Fels-Klerx, H. J., Sterrenburg, P., van Ruth, S. M., Scholtens-Toma, I. M. J., \& Kok, E. J. (2012). Halal assurance in food supply chains: Verification of halal certificates using audits and laboratory analysis. Trends in Food Science \& Technology, vol. 27 no. 2, pp. 109-119. http://doi.org/10.1016/j.tifs.2012.04.005

Van Waarden, F., \& Van Dalen, R. (2010). Hallmarking halal. Presented at the 3rd Biennial Conference of the ECPR Standing Groups on Regulation and Governance, University College, Dublin. Retrieved from http://www.regulation.upf.edu/dublin-10-papers/5F3.pdf

Verbeke, W., Rutsaert, P., Bonne, K., \& Vermeir, I. (2013). Credence quality coordination and consumers' willingness-to-pay for certified halal labelled meat. Meat Science, vol. 95 no. 4, pp. 790-797. http://doi.org/10.1016/j.meatsci.2013.04.042

Wan-Chik, R. Z. (2015). Information Credibility Assessment of Islamic and Quranic Information on the Web. In Proceedings of the 9th International Conference on Ubiquitous Information Management and Communication, 2007, New York, NY, USA: ACM, p. 25:1-25:7. http://doi.org/10.1145/2701126.2701185

Wilson, J. A. J., \& Liu, J. (2010). Shaping the Halal into a brand? Journal of Islamic Marketing, l(2), 107-123. http://doi.org/10.1108/17590831011055851 
Wilson, J. A. J., \& Liu, J. (2011). The challenges of Islamic branding: navigating emotions and halal. Journal of Islamic Marketing, 2(1), 28-42. http://doi.org/10.1108/17590831111115222

Wilson, J. (2012). Charting the rise of the halal market: tales from the field and looking forward. Journal of Islamic Marketing, 3(3). Retrieved from http://www.emeraldinsight.com/ journals.htm $?$ issn $=1759-0833 \&$ volume $=3 \&$ issue $=3 \&$ articleid $=17053868 \&$ show $=\mathrm{html}$

Wilson, J. A. J. (2014a). The halal phenomenon: An extension or a new paradigm? Social Business, 4(3), 255-271. http://doi.org/10.1362/204440814X14103454934294

Wilson, J. A. J. (2014b, March 6). Revisiting the philosophical arguments underpinning Islamic Finance and Halal. Retrieved from http://blog.thomsonreuters.com/index.php/revisitingphilosophical-arguments-underpinning-islamic-finance-halal/

Wilson, J. A. J. (2014c, May 7). Islamic economics 2.0 - Creating a Halal wealth and knowledge economy. Retrieved from http://www.zawya.com/story/Islamic_Finance_Gateway _Islamic_Economics_20_Creating_a_Halal_Wealth_and_Knowledge_Economy_By_Dr _Jonathan_AJ_Wilson_070514-pdf_080514073608/

Yeh, N.-C., \& Chen, Y.-J. (2011). On the Everyday Life Information Behavior of LOHAS Consumers: A Perspective of Lifestyle. Journal of Educational Media \& Library Sciences, vol. 48 no. 4 , pp. $489-510$.

Zhang, J., Liu, H., Sayogo, D. S., Picazo-Vela, S., \& Luna-Reyes, L. (In Press). Strengthening institutional-based trust for sustainable consumption: Lessons for smart disclosure. Government Information Quarterly. http://doi.org/10.1016/j.giq.2016.01.009

Zucker, L. G. (1986). Production of trust: Institutional sources of economic structure, 18401920. Research in Organizational Behavior, vol. 8, pp. 53-111. 


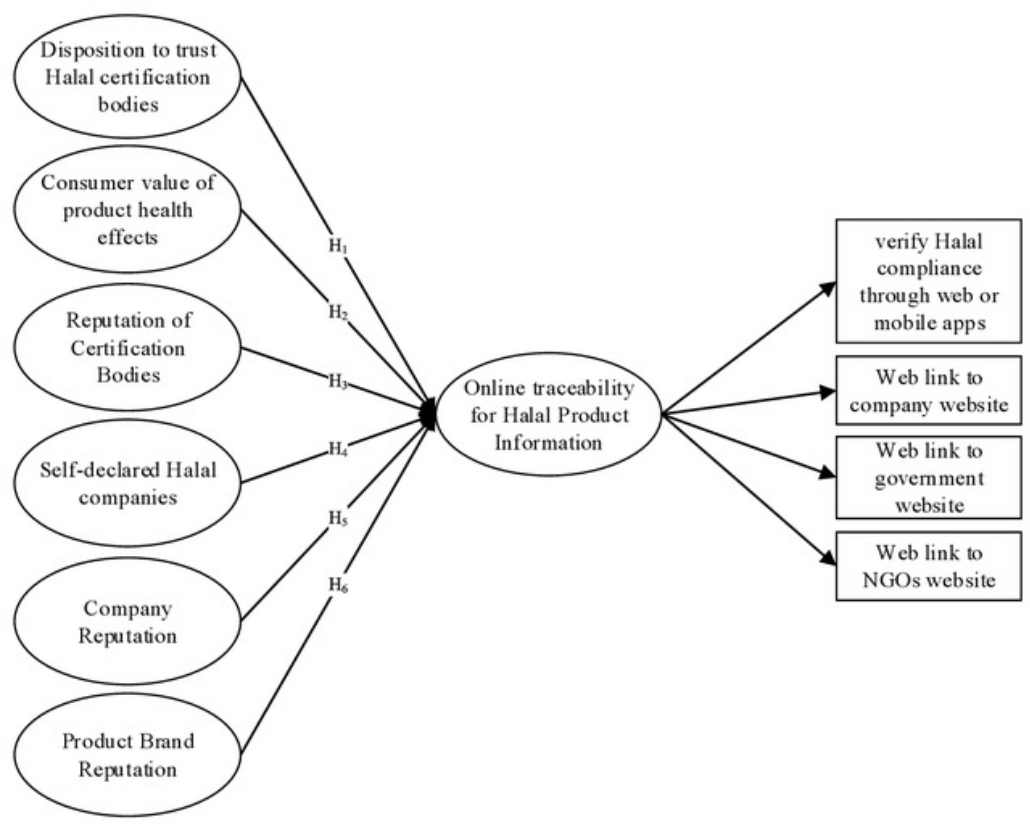

Figure 1. The Conceptual Model 


\section{Online traceability for Halal product information: perceptions of Muslim consumers in Indonesia}

ORIGINALITY REPORT

3

SIMILARITY INDEX
3\%

INTERNET SOURCES
$0 \%$

PUBLICATIONS
$3 \%$

STUDENT PAPERS

PRIMARY SOURCES 